Vol. 8, No. 1, 2021

https://doi.org/10.23939/eem2021.01.080

UDC 378

JEL Classification Code: I28

N. Podolchak
Lviv Polytechnic National University, Ukraine, Doctor, Professor
E-mail: nazar_podolchak@yahoo.com
ORCID ID: 0000-0002-0284-9601

N. Tsygylyk

Lviv Polytechnic National University, Ukraine, Assistant

E-mail: Natalia.V.Tsyhylyk@lpnu.ua

ORCID ID: 0000-0001-7038-380X

M. Khim

Lviv Polytechnic National University, Ukraine, Assistant

E-mail: Mariya.K.Khim@lpnu.ua

ORCID ID: 0000-0002-3151-6435

\title{
PROBLEMS AND PROSPECTS OF TRAINING CIVIL SERVANTS IN CONTEMPORARY UKRAINIAN REALITIES
}

\begin{abstract}
The purpose of the article is to identify the main problems in the basic and advanced training of civil servants. Using a retrospective review and taking into account the current situation, develop a strategic plan for further action to improve the system of training of civil servants. Outline priority areas and forms of advanced training of existing staff and basic training of new civil servants to meet the needs of highly qualified and competitive staff. In this article, the authors used the literature review method and analytical method to develop a strategic plan for further action to improve the training of civil servants. Based on these two methods, the priority areas and forms of advanced training of existing staff and basic training of new civil servants were outlined. It is established that the existing system of advanced training and basic training of civil servants still needs to be improved without moving towards the reforms carried out by the National Agency for Civil Service Affairs of Ukraine. The main attention in the basic training should be paid to the practical application of the acquired knowledge. The most effective for fulltime students will be the internship of study in public authorities lasting 1 week of each semester. In this case, the topic of internship should correspond mainly to the three subjects studied, and it should take place at the end of the semester as a result before the exam or test. The
\end{abstract}

results of the internship must be evaluated at least $20 \%$ of the total grade for the subject. Part-time students are invited to take an internship before the session. Civil service advanced training is encouraged to take place annually in order to be competitive in times of rapid change. Thus the direction of advanced training is recommended to choose independently and to coordinate with the direct head. The number of hours per year must be at least 7 ECTS credits (210 hours), as 1 ECTS credit is insufficient for the effective acquisition of new knowledge. The results of this research can be implemented in the educational process to meet the needs of highly qualified and competitive staff, namely civil servants of the new generation. Also, the findings may be of interest to the leadership of the National Agency for Civil Service Affairs of Ukraine for further effective civil service reform in Ukraine. This article highlights the main problems of today, developed a strategic plan for further improvement of the existing system of training and retraining of civil servants. This will help to take effective steps towards the existing problems and move in the right direction of further reforms, and thus speed up progress towards the EU.

Key words: Civil Servants, Civil Service Personnel, Training, Advanced Training, Public Administration, Training System, Strategic Plan. 


\section{Problems and prospects of training civil servants in contemporary ukrainian realities}

\section{Introduction}

The condition for the successful development of the state is the stability of its administration, regardless of external and internal factors. The standard of citizens' living in the state depends on the level of efficiency of public administration [3]. The main actors in government are civil servants who interact with society. The image of state power, and the state as a whole, often depends on them. Therefore, it is extremely important to carry out public administration reforms not only in the right direction, but also with appropriate effectiveness. It should be noted that the basis of effective work and successful career advancement is the knowledge obtained during training at the educational and qualification level of bachelor, master or during advanced training [11]. In order to obtain a new generation of public officials it is necessary to implement reforms in the knowledge acquisition system.

The current system of training new civil servants and advanced training of existing employees was preceded by a long process of formation and change, which was directly affects the position on the world stage and the leadership of Ukraine. On July 18, 2011 National Agency for Civil Service Affairs of Ukraine was created. It is the central executive body, which provides:

- formation and implementation of state policy in the field of civil service;

- functional management of the civil service.

In fact, it is part of the civil service management system, which consists of:

- Cabinet of Ministers of Ukraine;

- National Agency for Civil Service Affairs;

- Commissions for senior civil service and relevant tender commissions;

- heads of civil service;

- personnel management services.

On the website of the National Agency for Civil Service Affairs of Ukraine there is knowledge management portal which contains basic information related to the professional training of civil servants, heads of local administrations, their deputies and local government officials. In addition, National Agency for Civil Service Affairs of Ukraine manages:

- Center for Adaptation of the Civil Service to EU Standards;

- Ukrainian School of Government.
In the strategic plan of the National Agency for Civil Service Affairs of Ukraine for 2019-2022, the issue of professional training reforming is one of the priorities, and, therefore, our article is relevant and can find practical application [9].

\section{Literature review}

To better understand the current system of training and advanced training of civil servants we need to consider the background. Schematically, the main milestones are shown at Fig. 1. The first steps in shaping the system of professional education of civil servants were made back in 1992. At this time, the Institute of Public Administration and Self-Government was established. Two years later, the Decree of the President of Ukraine of May 30, 1995 №398 / 95 was issued [18].

It concerned the system of training, retraining and advanced training of civil servants. The first point in it was the Academy of Public Administration under the President of Ukraine with branches in Lviv, Dnipropetrovsk, Odessa and Kharkiv. By July 1 of the same year The Cabinet of Ministers had to determine a list of higher education institutions (HEIs) that would also train new civil servants and improve the skills of existing ones. In addition, it was necessary to create centers at each executive committee to ensure a coordinated and methodologically sound approach to training. It was expected that they would be financed from regional budgets.

After the liquidation of executive committees and the creation of regional state administrations, it was decided that they would become the founders of specialized centers with the purpose to provide the necessary knowledge of existing civil servants during the active changes and provide advice to public authorities. Therefore, in 1996 for their legalization the Cabinet of Ministers adopted Resolution 24224 of February 19, 1996 "On the Center for Advanced Training of Civil Servants and Managers of State Enterprises, Institutions and Organizations". It clearly stated that its coordination and control is carried out by the Head of the Civil Service [20]. At the same time, the center was the main generator of educational and methodological support. It is cooperated with the educational institutions, executive authorities and local governments. In the center was full-time, part- 


\section{N. Podolchak, N. Tsygylyk, M. Khim}

time and mixed form of training and advanced training. Thus, equal opportunities for civil servants of all categories were provided as much as possible, as well as an attempt was made to make training interesting and non-trivial.

A year later, on February 8, 1997, the Resolution of the Cabinet of Ministers No. 167 was promulgated. It was significant because it approved the Regulations on the system of training, retraining and advanced training of civil servants and the Regulations on a single procedure for training, retraining and advanced training of state enterprises, institutions and organizations. It affirmed the main components of the system and its management [14]. Thus the period of formation of personnel, organizational and methodological approaches was ended and the period of development was begun. However, due to the changes by
Resolutions of the Cabinet of Ministers No. 1071 from 30.07.1998 and No. 619 from 16.05.2002 it was not perfect. It should be noted that public administration as a branch of science with the degree was awarded on November 29, 1997. On that time the whole system reached a qualitatively new level [2].

On July 7, 2010 the Resolution of the Cabinet of Ministers No. 564 was issued. It is approved the Regulations on the system of training, specialization and advanced training of civil servants, heads of local state administrations, their first deputies and local government officials. In fact, it approved the changed types of professional development. The system of training of civil servants continued to change [15], although this was not the finish line. It was amended by six Resolutions until June 13, 2018.
1995-1996 pp.

apusvic management
approaches
Total control by the state
Centers
The work of civil servants to ensure the
interests of the state
Main Civil Service of Ukraine

2010-2021 pp.

Modern management approaches

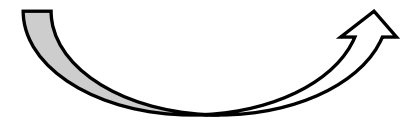

Selective control by the state Higher educational institutions, centers, etc.

The work of civil servants to ensure the interests of society

National Agency for Civil Service

Affairs of Ukraine

Fig. 1. The main milestones in the development of the system of advanced training and basic training of civil servants

Source: compiled by the authors based on the analysis of literary sources and their own works

Over time, some centers without first licensing in 1999-2000 were eliminated, and the complexity of the requirements further encouraged the centers to develop and improve their human resources. As a result of the adoption of the Law "On Higher Education" in 2014 and the Law "On Education" in 2017, the loss of the status of civil servants by the management of centers (according to the Law of Ukraine "On Civil Service" from December 10, 2015) transferred their activities to the regulation of general and educational legislation [7]. From this time begins the rapid reformatting from the closed system to the open. On February 6, 2019, Resolution No. 106 "On approval of the Regulations on the system of professional training of state investigators, heads of local state administrations, their first deputies, local government officials and deputies of local councils" was issued by the National Agency for Civil Service Affairs of Ukraine. It not only updated the terminology and introduced a new division of training programs, but also legalized the activities of various service providers. Moreover, 
the budget of public authorities provided for no more than $2 \%$ of the payroll to pay for relevant services [16]. And all this happened on the background of reducing the number of civil servants at all levels, but increasing their quality.

As part of the civil service reform, on December 1, 2017, the Cabinet of Ministers of Ukraine approved the Concept of reforming the system of professional training of civil servants, heads of local state administrations, their first deputies and deputies, local government officials and deputies of local councils. It outlines the issues of creating appropriate conditions to ensure continuous planned professional development and the creation of an appropriate system for all groups of civil servants. In addition, this Concept approves items on the development of the market of educational services in the field of professional development and quality assessment of educational services [19]. However, there are absolutely no issues of basic education for civil servants.

Within a month after its publication on May 10 , 2018, another order № 342 came into force. It approved the action plan for the implementation of the Concept of reforming the vocational training system of civil servants, heads of local administrations, their first deputies and deputies, local government officials and deputies of local councils. It described new methods of developing criteria for assessing the degree of risk from business activities, as well as determined the frequency of planned measures of state supervision (control) [13]. Although clearer evaluation requirements have been introduced, this provision has also proved to be imperfect. Thus, on March 3, 2021, by order № 165-r, another changes were made [12], not only about advanced training of civil servants but on including items on preparation. However, it should be noted that these changes need to be refined.

The Regulation' amendments by Resolution № 532 from June 25, 2020 stated that along with "Governance" appears "Public management and Administration". This was preceded by a large number of works by scientists who studied the essence of the concept of "Governance", "Public Administration" and "Public Management and Administration" [10].

It can be concluded that in governance the object is society, and in public administration - the state. Coercive mechanisms of influence are not used in public administration [1]. Thus, the transition to a fundamentally new system was indirectly legalized, but it also has its shortcomings and needs to be improved (Fig. 1).

\section{Methodological approach}

To research the period of formation of governance, public management and administration as specialties for training and areas of advanced training of civil servants, the method of analysis of literature sources was used. To develop a strategic plan for further action to improve the system of training of civil servants an analytical method was used. Based on these two methods, the synthesis of information outlined the priority areas and forms of advanced training of existing staff and basic training of new civil servants.

\section{Substantiation of the subject and methods of research}

Substantiation of the subject and research methods

The subject of the research is the problems of training of civil servants in modern Ukrainian realities, which covers the issues of both basic training and advanced training. This problem is extremely relevant because of:

- inclusion of this issue in the number of priorities for NAPS;

- changing of the whole paradigm of advanced training of civil servants in accordance with the Resolution of the Cabinet of Ministers of Ukraine No. 106 of 06.02.2019 [17];

- implementation of National Agency for Civil Service Affairs of Ukraine successive steps towards the development of a systematic approach to the training of civil servants;

- the presence of scientific interest in other authors on the training of civil servants, as evidenced by the presence of articles on this issue. Altough the study of this issue was conducted from different angles, most key points remain insufficiently covered [4].

The selected research methods are completely sufficient for a comprehensive consideration and solution of the problem, as they are characterized by the completeness and reliability of the results. The leveling of the influence of the subjective 
perception of the obtained facts was carried out by independent analysis of literature sources and analysis of all data. After that, a comparison of opinions and their generalization was carried out. That is why we can assume that the presented results are fully objective and reflect the real state of affairs.

\section{General and special characteristics of research Discussion of the obtained results}

After a detailed analysis of the information, it was found that training in the specialty "Public management and Administration" in Ukraine is carried out by 97 universities [5]*. Table 1 shows the territorial distribution of these universities.

Table 1

Territorial distribution of universities that conduct training in specialty 281 "Public Management and Administration"

\begin{tabular}{|c|c|c|c|c|}
\hline No. & Name of the region & $\begin{array}{l}\text { Area of the } \\
\text { region, } \mathrm{km}^{2}\end{array}$ & $\begin{array}{c}\text { Population, thousands } \\
\text { of people }\end{array}$ & $\begin{array}{c}\text { Number of universities, } \\
\text { units }\end{array}$ \\
\hline 1 & Vinnytsia & 26492 & 1529.1 & 2 \\
\hline 2 & Volyn & 20144 & 1027.4 & 0 \\
\hline 3 & Dnipro & 31923 & 3142.0 & 10 \\
\hline 4 & Donetsk* & 26517 & 4100.3 & 7 \\
\hline 5 & Zhytomyr & 29827 & 1195.5 & 1 \\
\hline 6 & Transcarpathian & 12753 & 1250.1 & 3 \\
\hline 7 & Zaporizhya & 27183 & 1666.5 & 6 \\
\hline 8 & Ivano-Frankivsk & 13927 & 1361.1 & 2 \\
\hline 9 & Kyiv and Kyiv city & 28121 & 4750.7 & 20 \\
\hline 10 & Kirovograd & 24588 & 920.1 & 1 \\
\hline 11 & Luhansk * & 26684 & 2121.3 & 3 \\
\hline 12 & Lviv & 21831 & 2497.8 & 6 \\
\hline 13 & Mykolayiv & 24585 & 1108.4 & 1 \\
\hline 14 & Odessa & 33314 & 2368.1 & 3 \\
\hline 15 & Poltava & 28750 & 1371.5 & 2 \\
\hline 16 & Rivne & 20051 & 1148.5 & 1 \\
\hline 17 & Sumy & 23832 & 1053.5 & 2 \\
\hline 18 & Ternopil & 13824 & 1030.6 & 2 \\
\hline 19 & Kharkiv & 31418 & 2633.8 & 11 \\
\hline 20 & Kherson & 28461 & 1016.7 & 1 \\
\hline 21 & Khmelnytskyi & 20629 & 1243.8 & 4 \\
\hline 22 & Cherkasy & 20916 & 1178.3 & 3 \\
\hline 23 & Chernivtsi & 8096 & 896.6 & 1 \\
\hline 24 & Chernihiv & 31903 & 976.7 & 3 \\
\hline
\end{tabular}

* - as Donetsk, Luhansk region and Crimea are temporarily occupied territories for 2021 - we do not take them into account in the calculations

Source: systematized by the authors

The Table 1 shows that there is no uniform distribution of universities in the regions. The largest number of them is available in Kyiv, Kharkiv, Dnipro, Lviv and Zaporizhia regions, which covers the East, Center and West of Ukraine. There are 20 universities that train future civil servants in Kyiv region, 11 universities in Kharkiv region, 10 universities in Dnipro region, 6 universities in the Lviv region, and 6 universities in Zaporizhia region. At the same time, their areas are respectively $28121 \mathrm{~km}^{2}, 31418 \mathrm{~km}^{2}, 31923 \mathrm{~km}^{2}, 21831 \mathrm{~km}^{2}$, $1666.5 \mathrm{~km}^{2}$. There are 2,119 civil servants in Kyiv region and Regional State Administrations, 462 of which are in the Regional State Administration and 1.467 in the District State Administration. There are 2.449 civil servants 


\section{Problems and prospects of training civil servants in contemporary ukrainian realities}

in the Kharkiv Regional and District state administrations, 608 of which are in the Regional state administration and 1,841 in the Districtl state administration. There are 1,639 civil servants in the Dnipro Regional and District state administrations, 577 of which are in the Regional state administration and 1,062 in the District state administration. There are 1983 civil servants in the Lviv Regional and District state administrations, 540 of which are in the Regional state administration and 1443 in the Distrct state administration. There are 1,429 civil servants in the Zaporizhya Region and District State Administrations, of which 538 are in the Regional State Administration and 891 in the District State Administration. At the same time, the number of universities that study the specialty "Public Management and Administration" does not depend on the area of the region, as well as on the number of civil servants already working in it. The population of the regions has little effect on this number of universities. The determining factor is the so-called "popularity of cities": Kharkiv was the capital of Ukraine, Kyiv is its capital, and Lviv is considered the cultural capital of Ukraine, Dnipro and Zaporizhia are large industrial centers.

There is a significant shortage of institutions for the training of civil servants in the Volyn region, although there are 5 in the direction of management and administration. The area of the Volyn region is $20144 \mathrm{~km}^{2}$ with a population 1027.4 thousands of people (as of 1 January 2021). It is $2.5 \%$ of the total population of Ukraine. At the same time, 1419 civil servants work in Volyn Regional and District state administrations, 357 of them are in the Regional state administration and 1062 of them are in the District state administration [8]. There are only one university in Zhytomyr, Kirovohrad, Mykolaiv, Rivne, Kherson and Chernivtsi regions that train staff in the specialty "Public Management and Administration".

Training in the specialty "Public Management and Administration" takes place at the bachelor's and master's educational levels. Form of study is full-time and part-time. As National Agency for Civil Service Affairs of Ukraine established direction on the formation of new generation of civil servants, it is necessary to constantly monitor the content of programs, to ensure their compliance with the requirements of the time. To do this, the heads of university departments should be in constant cooperation with the National Agency for Civil Service Affairs of Ukraine, and the National Agency for Civil Service Affairs of Ukraine should create a working group, which would include heads of departments - leaders from each region in this area of training. Leadership is proposed to be determined by the number and quality of trained graduates in the specialty "Public Management and Administration".

In addition, in the process of training future civil servants, considerable attention should be paid to the practical application of the acquired knowledge. To this end, it is necessary to increase the number of hours provided for student practice. The most effective for full-time students will be the internship of study in public authorities lasting 1 week of each semester. It is recommended to choose the topic in accordance with the three main subjects studied in the current semester. In this case, the choice of topic is given to the student, and the practice take place at the end of the semester as a result before the exam or test. The grade for the internship must be at least $20 \%$ of the total score for the subject. For part-time students, internships are recommended before the session. This approach will ensure the effective assimilation of knowledge and their use in practice and, in addition, will maximize the integration of theory and practice, which is extremely important for further effective work of future civil servants.

In Ukraine advanced training of civil servants are provided by: 20 specialized centers, the Institute of Advanced Training in Kyiv, 4 regional institutes of public administration (in Lviv, Odessa, Dnipro and Kharkiv), the Ukrainian School of Government, created for this purpose by National Agency for Civil Service Affairs of Ukraine, departments of 110 higher educational institutions of the corresponding direction and some institutions of postgraduate education [6]. This number of institutions is due to the fact that according to the law, every civil servant is obliged to undergo advanced training in such a way that during the year for various forms of training the total number of hours was at least 30 hours (1 ECTS credit). Form of study - evening, correspondence and distance. According to the changes approved by the Resolution of the Cabinet of Ministers of June 25, 2020 introduced in the Regulation No. 106 of 


\section{N. Podolchak, N. Tsygylyk, M. Khim}

February 6, 2019 on the system of professional training of civil servants, heads of local state administrations, their first deputies and deputies, local government officials and deputies of local councils the share of self-education should be no more than $50 \%$ of ECTS credits received.

On the website of the National Agency for Civil Service Affairs of Ukraine, the section on vocational training provides information on available opportunities for various types of training, which includes:

- general short-term programs;

- special short-term programs;

- general professional (certificate) program;

- special professional (certificate) program;

- educational and professional program;

- educational and scientific program;

- self-study.

This provides a search by region, which significantly saves time spent on the website. However, it should be noted that the information provided needs to be expanded. For example, it is necessary to post information about all universities that conduct training in the specialty "Public Management and Administration". There is currently no necessary information in the self-study section, so specialists from universities and advanced training centers should be involved to speed up its filling.

In the world's leading countries, the amount of training that civil servants must undergo each year in the framework of advanced training is from 3 to 7 ECTS credits [7].

Given the situation in our country, the modernization of the civil service and accession to the EU it will be justified to introduce advanced training of civil servants in the amount of 7 ECTS credits (210 hours) each year, leaving the allowable amount of self-education at no more than $50 \%$. At the same time it is necessary to ensure mandatory quality control of the results of such self-education by the relevant Centers and universities. If the self-study results are unsuccessful, such a civil servant should not be sent for re-training, but under the guidance of a mentor. In parallel with such innovations, the results of advanced training should be linked to the system of setting allowances and surcharges for civil servants. This approach completely eliminates the risk of ineffective selfeducation and training. The proposed system of advanced training is shown at Fig. 2.

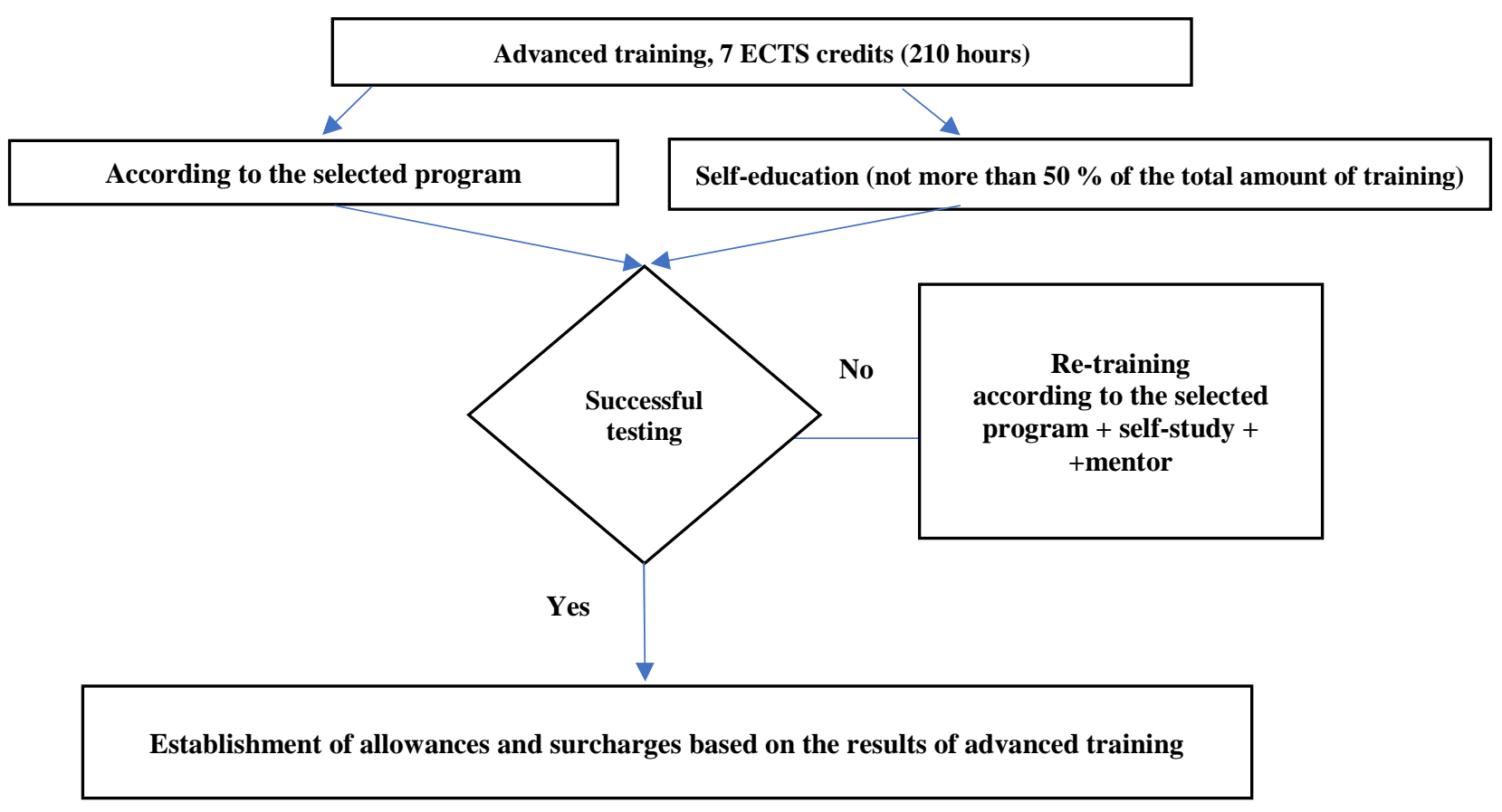

Fig. 2. Block diagram of the system of advanced training of civil servants

Source: compiled by the authors 


\section{Problems and prospects of training civil servants in contemporary ukrainian realities}

Given the uneven distribution of universities that provide training in the field of "Public Management and Administration" in Ukraine, as well as threats to the effective implementation of the learning process arising in connection with the Covid-19 pandemic, it is necessary to introduce new methods of distance learning. As shown practice at Lviv Polytechnic National University, learning developed on the basis of the MOODLE platform (Modular Object-Oriented Dynamic Learning Environment) is extremely effective. It belongs to the automated information systems of the LMS class (Learning Management System), and is used in more than 30.000 educational institutions around the world. Thanks to its architecture, it allows the teacher to independently create and manage the training course: to upload lecture material and tasks for practical work, download self-developed tests with automated testing, control access to it and time of submission for testing, organize chat, etc. It is very convenient that you can download and use presentations, tables, diagrams and videos without restrictions. Automated calculation of points obtained for tests and a summary table of grades for all types of work with the resulting sum of points greatly facilitates the work of the teacher. The function of individual communication with the student in the form of commentary on works, exchange of attached files, forums and chats not only equates distance learning to full-time, but also makes it much more effective.

Given all the advantages of such a training system, it is recommended to implement it to improve the skills of existing civil servants. This will make more efficient use of the time allotted for training.

In addition, the lack of English language proficiency is a significant shortcoming in the training of civil servants. Given that Ukraine is confidently moving towards the EU, and civil servants actually represent the state, it is necessary to introduce the need to speak English at a level not lower than B2 with the mandatory presence of a certificate. To do this, it is necessary to introduce the study of business English during all semesters of student study, as well as in the amount of 1 ECTS credit for advanced training. This 1 ECTS credit must be included in the total annual 7 credits. Ukraine is confident in joining the EU, and civil servants actually represent the state, that is why it is necessary to introduce a requirement to speak English at not lower than B2 level with the mandatory presence of a certificate. To do this, it is necessary to introduce the study of business English during all semesters, as well as for advanced training in the amount of 1 ECTS credit. This 1 ECTS credit must be included in the total annual 7 credits.

In summary, the strategic plan for further improvement of the existing system of future civil servants training will include:

1. Monitoring the content of programs, to ensure their compliance with the requirements of the time; introducing close cooperation of the National Agency for Civil Service Affairs of Ukraine with the heads of departments of universities leaders from each region of Ukraine in this area of training. Leadership is proposed to be determined by the number and quality of trained graduates in the specialty "Public Management and Administration".

2. Review the territorial feasibility of a large number of universities that provide training in the specialty "Public Management and Administration", consider the possibility of opening new departments in cities where they are lacking.

3. Introduction of training developed on the basis of the MOODLE platform.

4. Introduction the internship of study in public authorities lasting 1 week of each semester.

5. Introduction of business English during all semesters of students' studies.

The strategic plan for further improvement of the existing system of advanced training of already working civil servants will provide:

1. Increasing the duration of advanced training of civil servants during the year to 7 ECTS credits (210 hours). Self-education should not exceed $50 \%$ of the total amount of training.

2. Introduction of testing based on the results of advanced training.

3. Establishing surcharges and allowances for civil servants on the basis of such testing (Fig. 2).

4. Introduction of business English in the amount of 1 ECTS credit.

\section{Conclusions}

Based on the results of research, the following conclusions can be drawn:

1. There is a significant territorial unevenness of the location of institutions that provide training 
and retraining in the specialty "Public Management and Administration". It is necessary to reconsider the expediency of their accumulation in one area and the lack of it in another.

2. Given the modernization of the civil service in accordance with modern world standards, the existing system of future civil servants training in the specialty "Public Management and Administration", as well as advanced training of existing staff need significant improvement.

3. The main attention should be paid to: the coordinated work of the National Agency for Civil Service Affairs of Ukraine and the relevant profile departments of universities; English language proficiency at a level not lower than B2; combination of theoretical knowledge and practical skills.

4. In order to increase the effectiveness of advanced training of civil servants, its results should be linked to the establishment of allowances and surcharges, as well as increase the number of hours to 7 ECTS credits (120 hours).

5. Given today's challenges, training should be implemented on the basis of the MOODLE platform - one of the most effective and convenient that exists today.

\section{Prospects for further research}

In the future, it will be useful to explore the progress in the implementation of the National Agency for Civil Service Affairs plan for 20192022 in the context of the formation of a new generation of civil servants.

\section{References}

1. Al-Atti, I.V. (2018). Publichne upravlinnia: sutnist $i$ vyznachennia. Aspects of public administration, 6 (8), 35-41. (in Ukrainian).

2. Bosak, O. Z. (2010). Publichne upravlinnia yak nova model upravlinnia u derzhavnomu sektori. Public administration: theory and practice: collection of scientific works, 2. Retrived from: http://www.nbuv.gov.ua/ejournals/dutp/2010_2/txts/10bozuds.pdf

3. Vashchenko, K., Kuprii, V., Chmyha, V., Tokarchuk, T., Rykova, L., \& Vernyhor, Y. (2019). Stan systemy profesiinoho navchannia derzhavnykh sluzhbovtsiv, holiv mistsevykh derzhavnykh administratsii, yikh pershykh zastupnykiv ta zastupnykiv, posadovykh osib mistsevoho samovriaduvannia, deputativ mistsevykh rad: dopovid. Retrived from: https://nads.gov.ual storagelapp/sites $/ 5 / \% D 0 \% B F \% D 1 \% 80 \% D 0 \% B E \%$ $D 1 \% 84 \% D 0 \% B 5 \% D 1 \% 81 \% D 1 \% 96 \% D 0 \% B 9 \% D$ $0 \% B D \% D 0 \% B 5 \% 20 \% D 0 \% B D \% D 0 \% B 0 \% D 0 \% B 2$ $\% D 1 \% 87 \% D 0 \% B 0 \% D 0 \% B D \% D 0 \% B D \% D 1 \% 8 F /$ preview_2019-07-16_block_dopovid_170x240.pdf

4. Vytko, T. Y. (2018). Derzhavnyi sluzhbovets $v$ umovakh reformuvannia derzhavnoho upravlinnia $v$ Ukraini. Aspects of public administration, 3(6), 3947. [in Ukrainian].

5. Vuzy Lvova: spetsialnist publichne upravlinnia ta administruvannia - dovidnyk VNZ. (2021). Osvita.UA. Retrived from: https://osvita.ua/vnz/ guide/search17-0-61-85-0.html [in Ukrainian].

6. buhgalter.com.ua. (2020, April 21). Zmina paradyhmy pidvyshchennia kvalifikatsii publichnykh sluzhbovtsiv $u$ rehionakh. Bukhhalter.Com.Ua. Retrived from: https://buhgalter.com.ua/articles/kadrova-sprava/ zmina-paradigmi-pidvishchennya-kvalifikatsiyipublichnih-sluzhbovtsiv/ [in Ukrainian].

7. Zakon Ukrainy "Pro derzhavnu sluzhbu": pryiniatyi 10 hrudnia 2015 r. No. 889-VIII. Vidomosti Verkhovnoi Rady. 2016. No. 4. S. 43. [in Ukrainian].

8. NADS. (2018). Stratehichnyi plan diialnosti NADS on 2019-2022 years. Retrived from: https://nads.gov. ua/storagelapp/sites $/ 5 / \% D 0 \% B F \% D 0 \% B B \% D 0 \% B 0 \%$ $D 0 \% B D \% D 0 \% B 8 \% 20 \% D 1 \% 82 \% D 0 \% B 0 \% 20 \% D 0 \%$ B7\%D0\%B2\%D1\%96\%D1\%82\%D0\%B8/strat_plan_ nads-2019-2022.pdf [in Ukrainian].

9. NADS. (2020). Informatsiia pro kilkisnyi sklad derzhavnykh sluzhbovtsiv $v$ orhanakh derzhavnoi vlady. Retrived from: https://nads.gov.ua/storage/ app/sites $/ 5 / \% D 0 \% B F \% D 0 \% B B \% D 0 \% B 0 \% D 0 \% B$ $D \% D 0 \% B 8 \% 20 \% D 1 \% 82 \% D 0 \% B 0 \% 20 \% D 0 \% B 7$ $\% D 0 \% B 2 \% D 1 \% 96 \% D 1 \% 82 \% D 0 \% B 8 / k s d s \_2020 / k$ sds-1-kv.pdf [in Ukrainian].

10. Obushna, N. I. (2015). Publichne upravlinnia yak nova model orhanizatsii derzhavnoho upravlinnia v Ukraini: teoretychnyi aspekt. Efektyvnist derzhavnoho upravlinnia, 44(1), 53-63. [in Ukrainian].

11. Podolchak, N. Y., Khim, M. K. \& Tsyhylyk, N. V. (2020). Udoskonalennia systemy otsiniuvannia efektyvnosti roboty derzhavnykh sluzhbovtsiv Ukrainy katehorii B ta $V$ yak odyn iz faktoriv pidvyshchennia profesiinoho ta osobystisnoho rozvytku. Bulletin of the National academy of public administration under the President of Ukraine, 2(97), 117-128. [in Ukrainian].

12. Pro vnesennia zmin do rozporiadzhen Kabinetu Ministriv Ukrainy vid 1 hrudnia 2017 r. No. 974 i vid 10 travnia 2018 r. No. 342 Rozporiadzhennia Kabinetu Kabinetu Ministriv vid 3 bereznia 2021r. No. 342. Retrived from: https://zakon. rada.gov.ua/laws/show/165-2021-\%D1\%80 [in Ukrainian]. 
Problems and prospects of training civil servants in contemporary ukrainian realities

13. Pro zatverdzhennia metodyk rozroblennia kryteriiv, za yakymy otsiniuietsia stupin ryzyku vid provadzhennia hospodarskoi diialnosti ta vyznachaietsia periodychnist provedennia planovykh zakhodiv derzhavnoho nahliadu (kontroliu), a takozh unifikovanykh form aktiv, shcho skladaiutsia za rezultatamy provedennia planovykh (pozaplanovykh) zakhodiv derzhavnoho nahliadu (kontroliu): Postanova Kabinetu Kabinetu Ministriv vid 10 travnia 2018 r. No. 342. Retrived from: https://zakon.rada.gov.ua/laws/show/3422018-\%D0\%BF\#Text [in Ukrainian].

14. Pro zatverdzhennia Polozhennia pro systemu pidhotovky, perepidhotovky ta pidvyshchennia kvalifikatsii derzhavnykh sluzhbovtsiv i Polozhennia pro yedynyi poriadok pidhotovky, perepidhotovky ta pidvyshchennia kvalifikatsii kerivnykiv derzhavnykh pidpryiemstv, ustanov i orhanizatsii : Postanova Kabinetu Ministriv vid 8 liutoho 1997 r. No. 167. Retrived from: https://zakon.rada.gov.ua/laws/ show/ 167-97-\%D0\%BF\#Text [in Ukrainian].

15. Pro zatverdzhennia Polozhennia pro systemu pidhotovky, perepidhotovky ta pidvyshchennia kvalifikatsii derzhavnykh sluzhbovtsiv $i$ posadovykh osib mistsevoho samovriaduvannia : Postanova Kabinetu Ministriv vid 7 lypnia 2010 r. No. 564. Retrived from: https://www.kmu.gov.ua/npas/ 243532378 [in Ukrainian].

16. Pro zatverdzhennia Polozhennia pro systemu profesiinoho navchannia derzhavnykh slizhbovtsiv, holiv mistsevykh derzhavnykh administratsii, yikh pershykh zastupnykiv, posadovykh osib mistsevoho samovriaduvannia ta deputativ mistsevykh rad: Postanova Kabinetu Ministriv vid 6 liutoho 2019 r.
No. 106. Retrived from: https://zakon.rada.gov.ua/ laws/show/106-2019-\%D0\%BF\#Text [in Ukrainian].

17. Pro zatverdzhennia Polozhennia pro systemu profesiinoho navchannia derzhavnykh sluzhbovtsiv, holiv mistsevykh derzhavnykh administratsii, yikh pershykh zastupnykiv ta zastupnykiv, posadovykh osib mistsevoho samovriaduvannia ta deputativ mistsevykh rad: Postanova Kabinetu Ministriv vid 6 liutoho 2019 r. No. 106. Retrived from: https://zakon.rada.gov.ua/laws/show/106-2019$\%$ D0\%BF\#Text [in Ukrainian].

18. Pro systemu pidhotovky, perepidhotovky ta pidvyshchennia kvalifikatsii derzhavnykh sluzhbovtsiv. Iz zminamy $i$ dopovnenniamy, vnesenymy Ukazamy Prezydenta Ukrainy vid 5 kvitnia 1996 roku No. 247/96, vid 27 sichnia 1999 roku No. 70/99: Ukaz Prezydenta Ukrainy vid 30 travnia 1995 r. Retrived from: https://zakon.rada. gov.ua/laws/show/398/95\#Text [in Ukrainian].

19. Pro skhvalennia Kontseptsii reformuvannia systemy profesiinoho navchannia derzhavnykh sluzhbovtsiv, holiv mistsevykh derzhavnykh administratsii, yikh pershykh zastupnykiv ta zastupnykiv, posadovykh osib mistsevoho samovriaduvannia ta deputativ mistsevykh rad: Rozporiadzhennia Kabinetu Kabinetu Ministriv vid 1 hrudnia 2017 r. No. 974-r. Retrived from: https://zakon.rada.gov.ua/laws/ show/974-2017-\%D1\%80\#Text [in Ukrainian].

20. Pro tsentry perepidhotovky ta pidvyshchennia kvalifikatsii pratsivnykiv orhaniv derzhavnoi vlady, orhaniv mistsevoho samovriaduvannia, kerivnykiv derzhavnykh pidpryiemstv, ustanov ta orhanizatsii: Postanova Kabinetu Ministriv vid 19 liutoho 1996 r. No. 224. Retrived from: https://zakon.rada.gov.ual laws/show/224-96-\%D0\%BF\#Text [in Ukrainian]. 